\title{
Suppression of plasma FSH concentrations with bovine follicular fluid blocks ovulation in GnRH-treated seasonally anoestrous ewes
}

\author{
B. J. McLeod $\ddagger$ and A. S. McNeilly*
}

A.F.R.C. Research Group on Hormones and Farm Animal Reproduction, University of Nottingham

School of Agriculture, Sutton Bonington, Loughborough, Leics LE12 5RD, and

${ }^{*}$ M.R.C. Reproductive Biology Unit, University of Edinburgh Centre for Reproductive Biology, 37 Chalmers Street, Edinburgh EH3 9EW, U.K.

\begin{abstract}
Summary. The specific requirement for FSH in the final stages of preovulatory follicle development was assessed in seasonally anoestrous ewes given 2-h injections of GnRH (250 ng/injection), with $(\mathrm{N}=10)$ or without $(\mathrm{N}=10)$ concurrent treatment with bovine follicular fluid (bFF: $2 \mathrm{ml}$ given i.v. at 8 -h intervals). Treatment with bFF significantly $(P<0.01)$ suppressed plasma FSH concentrations, but, at least for the first $30 \mathrm{~h}$ of treatment, did not influence the magnitude of GnRH-induced LH episodes (mean max. conc. $3.00 \pm 0.39$ and $3.63 \pm 0.51 \mathrm{ng} / \mathrm{ml}$ for bFF-treated and control ewes, respectively). Of 10 animals treated with $\mathrm{GnRH}$ for $72 \mathrm{~h}, 5 / 5$ control ewes showed oestrus and ovulated whereas $0 / 5 \mathrm{bFF}$-treated ewes showed oestrus or ovulated in response to GnRH treatment. There was, however, a transient $(13.2 \pm 1.0 \mathrm{~h})$ increase in plasma $\mathrm{LH}$ concentrations in the ewes given bFF (mean max. conc. $4.64 \pm 1.57 \mathrm{ng} / \mathrm{ml}$ ), which was coincident with the preovulatory $\mathrm{LH}$ surge recorded in animals given $\mathrm{GnRH}$ alone. In $10 \mathrm{GnRH}$-treated ewes slaughtered after $32 \mathrm{~h}$ of treatment, the mean diameter of the largest antral follicle was significantly $(P<0.001)$ greater in control ewes $(5.92 \pm 0.17 \mathrm{~mm})$ than in animals that were also given $\mathrm{bFF}$ $(3.94 \pm 0.14 \mathrm{~mm})$. In addition, the incidence of atresia in the 3 largest antral follicles present at this time was greater in bFF-treated ewes. These results show that, when plasma FSH concentrations are suppressed by administration of bFF, although the magnitude of $\mathrm{GnRH}$-induced LH episodes is unchanged, preovulatory follicular development is impaired and ovulation does not occur. This may be indicative of a specific requirement for $\mathrm{FSH}$ in the final stages of preovulatory follicle development, or due to direct inhibitory effects of bovine follicular fluid.
\end{abstract}

\section{Introduction}

The importance of FSH in the final stages of growth and development of the preovulatory follicle in the ewe, is uncertain. Specific suppression of FSH secretion during the follicular phase of the oestrous cycle, by administration of charcoal-treated bovine follicular fluid, blocks ovulation (Miller et al., 1979; McNeilly, 1984). This suggests that plasma FSH concentrations are critical. However, it has also been demonstrated that the administration of purified $\mathrm{LH}$ alone is sufficient to induce ovulation in seasonally anoestrous ewes, at least in those of some breeds (McNeilly et al., 1982,1985 ). In addition, LH, but not FSH, appears to be responsible for the induction of ovulation in seasonally anoestrous ewes treated with low doses of GnRH (McLeod et al., 1982, 1983; McLeod \& Haresign, 1987). Wallace \& McNeilly (1986) have shown that when naturally-cycling ewes are treated with follicular fluid from cows for a period of at least 3 days, only small antral 
follicles ( $\leqslant 2.7 \mathrm{~mm}$ diameter) are present in the ovaries. Collectively, these results suggest that FSH plays a primary role in the growth and maturation of small- and medium-sized follicles, but when antral follicles reach a certain critical stage of development, then LH alone is sufficient to promote the final stages of preovulatory growth. Consequently, when plasma FSH concentrations are inadequate, follicular development is restricted and there are no follicles present that are capable of responding to the $\mathrm{LH}$ stimulus.

In seasonally anoestrous ewes, a prolonged period of treatment with low doses of GnRH will consistently induce development of preovulatory follicles which culminates in ovulation (Hunter et al., 1986). In the current experiments, GnRH-treated seasonally anoestrous ewes were used to monitor the final stages of development of the preovulatory follicle. Some of these animals were treated concurrently with bovine follicular fluid to suppress plasma concentrations of FSH.

\section{Materials and Methods}

Animals and management. Twenty seasonally anoestrous (mid-anoestrus) Romney ewes (mean \pm s.e.m. liveweight $67.7 \pm 1.4 \mathrm{~kg}$ ) were run as a single group and were maintained on pasture except during the experimental period, when they were housed indoors under conditions of natural daylength and temperature. When housed, they were fed a diet of concentrates and hay, with fresh water always available.

Treatment and blood sampling. All 20 ewes were pretreated with progesterone, administered via an intravaginal device (C.I.D.R.: AHI Plastic Moulding Co, Hamilton, New Zealand) that remained in situ for 14 days. From the time of progesterone withdrawal, all ewes received i.v. injections (via an indwelling jugular vein catheter) of 250 ng GNRH (Lutal: Fabwerke Hoechst A.G., Frankfurt, West Germany) in $2 \mathrm{ml}$ sterile saline $(0.9 \% \mathrm{NaCl}$, w/v) given at 2-h intervals. Half of the animals were also injected with charcoal-treated bovine follicular fluid (bFF), which had been collected and prepared as described by McNeilly (1984). The biological activity of this preparation was 9844 units/ml, as assessed by the method of Tsonis et al. (1986). The bFF ( $2 \mathrm{ml})$ was administered i.v. via the catheter at 8-h intervals, with the first injection being given at the time of the first GnRH injection. Vasectomized Finnish Landrace rams were run with the ewes throughout the period of progesterone-priming and until the end of GnRH treatment, for the detection of oestrus.

Experiment 1. Ten animals were treated with GnRH plus bFF (Ewes 1-5) or with GnRH alone (Ewes 6-10) for a period of $72 \mathrm{~h}$. Blood samples $(2 \mathrm{ml})$ were collected via the jugular vein catheter, from $6 \mathrm{~h}$ before the start until $24 \mathrm{~h}$ after the end of the treatment period. Samples were taken at $15-\mathrm{min}$ intervals from -6 to $+12 \mathrm{~h}$ and from +24 to $+36 \mathrm{~h}$, and at $2-\mathrm{h}$ intervals during the intervening periods. Ovarian activity was assessed by laparoscopy 4 days before the start, and again 3 days after the end of GnRH treatment.

Experiment 2. Two groups of 5 ewes were treated with GnRH plus bFF (Ewes 11-15) or with GnRH alone (Ewes 16-20) for a period of $32 \mathrm{~h}$. Blood samples were taken at 2-h intervals throughout the period of treatment. All ewes were slaughtered within $1 \mathrm{~h}$ after the last $\mathrm{GnRH}$ injection, at which time their ovaries were recovered and fixed in buffered formal saline ( $10 \%$ formalin) for later appraisal.

Hormone assays. Plasma LH concentrations were measured by the method of Foster \& Crighton (1974) as modified by McLeod et al. (1982). The limit of sensitivity within this study was $0 \cdot 15 \mathrm{ng} \mathrm{NIH-LH-S24} \mathrm{equiv./ml} \mathrm{and} \mathrm{the}$ intra- and inter-assay coefficients of variation were both $<10 \%$. Concentrations of FSH were determined by the method of McNeilly et al. (1976). The limit of sensitivity of this assay was $4 \cdot 0 \mathrm{ng} \mathrm{NIH}-\mathrm{FSH}-\mathrm{S} 14 \mathrm{equiv} . / \mathrm{ml}$ plasma and the inter- and intra-assay coefficients of variation were 11 and $7 \%$ respectively.

Follicle assessment. The ovaries collected in Exp. 2 were sectioned into $0 \cdot 5-\mathrm{mm}$ slices, the 3 largest antral follicles from each animal were identified and their mean diameter measured. Selected $6 \mu \mathrm{m}$ sections of these follicles were stained (haematoxylin, eosin and celestin blue) for histological assessment of atresia by the method of Carson $e t$ al. (1979), as described by McNeilly et al. (1986).

Analysis of data. Differences in mean plasma concentrations of LH and FSH, the magnitude of GnRH-induced LH episodes and in mean follicle diameters were assessed by one-way analysis of variance. Differences in the incidence of follicle atresia were compared by $\chi^{2}$ analysis. All values are reported as mean \pm s.e.m.

\section{Results}

\section{Experiment 1}

Oestrus and ovulation. Laparoscopic examination 4 days before the start of treatment showed that all ewes had regressed reproductive tracts typical of the anoestrous ewe. All ewes treated with 

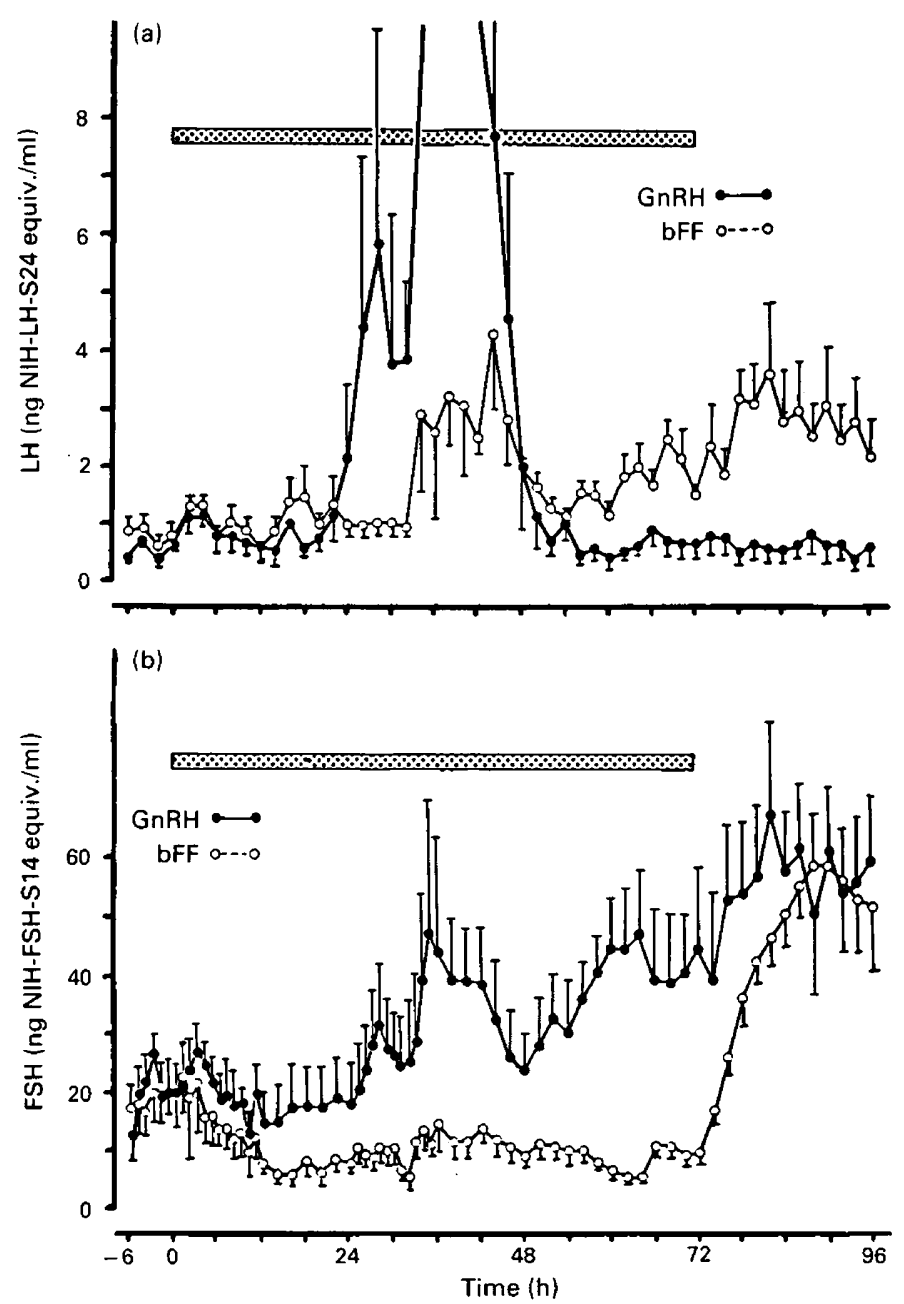

Fig. 1. Mean ( \pm s.e.m.) plasma LH (a) and FSH (b) concentrations in seasonally anoestrous ewes treated with $250 \mathrm{ng} \mathrm{GnRH}$ at 2-h intervals for $72 \mathrm{~h}$, with $(\mathrm{O}-\mathrm{O})$ or without (-O) concurrent administration of bFF ( $2 \mathrm{ml})$ given at 8-h intervals. Blood samples were taken at 2-h intervals, from $6 \mathrm{~h}$ before the start until $24 \mathrm{~h}$ after the end of the treatment period (shown by the horizontal bar).

GnRH alone showed overt oestrus, with the mean time of onset being $31.8 \pm 1.8 \mathrm{~h}$ after the start of treatment, and when examined by laparoscopy 3 days later, all had ovulated. None of the ewes treated with GnRH plus bFF displayed oestrus or had ovulated at the time of the second laparoscopy.

Plasma LH concentrations. The mean LH profiles, based on blood samples collected at 2-h intervals, are shown in Fig. 1(a). Over the pretreatment period, and for at least the first $24 \mathrm{~h}$ of GnRH treatment, mean plasma LH concentrations did not differ significantly between the two treatment groups. A preovulatory LH surge (mean maximum conc. $96.4 \pm 11.4 \mathrm{ng} / \mathrm{ml}$ ) was recorded in 5/5 control ewes treated with GnRH alone, with a mean time of onset of $32.0 \pm 2.4 \mathrm{~h}$ after the start of treatment. In these animals plasma LH concentrations then returned to pretreatment levels, and thereafter remained low. None of the ewes treated with bFF showed a preovulatory-surge release of $\mathrm{LH}$, but in these animals there was a significant elevation in LH 

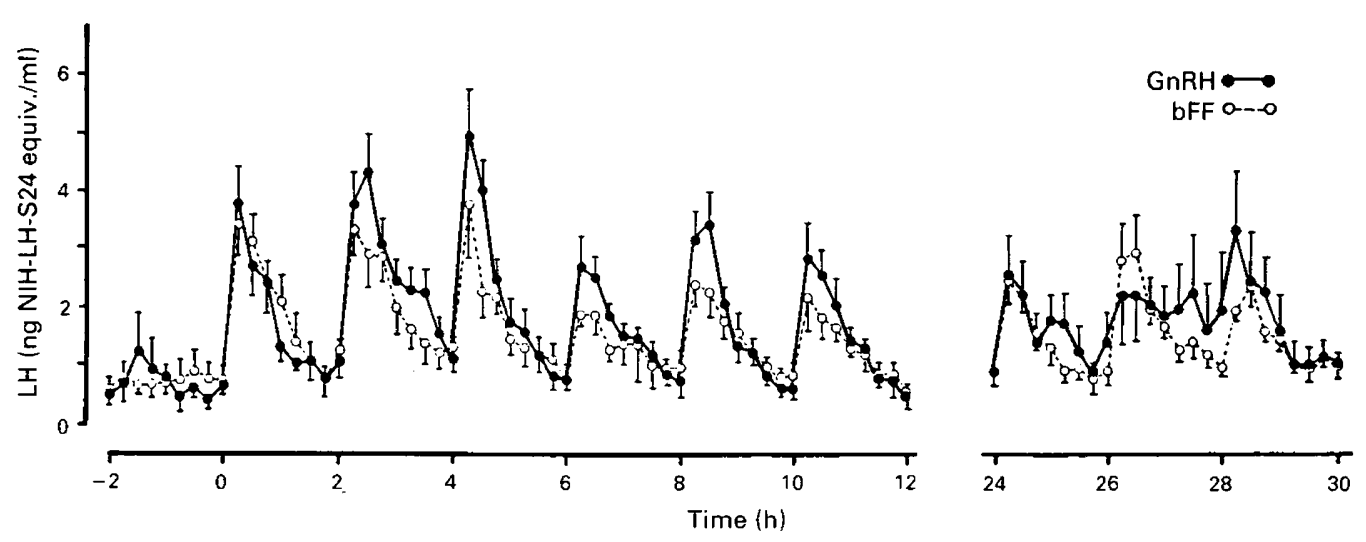

Fig. 2. Mean ( \pm s.e.m.) plasma LH concentrations in seasonally anoestrous ewes in response to i.v. injections of $\mathrm{GnRH}\left(250 \mathrm{ng} /\right.$ injection) with $\left(\mathrm{O}_{---\mathrm{O}}\right)$ or without $(-0)$ concurrent treatment with bFF $(2 \mathrm{ml})$ given at 8 - $\mathrm{h}$ intervals.

concentrations (mean maximum conc. $4.64 \pm 1.57 \mathrm{ng} / \mathrm{ml}$, see Fig. $3 \mathrm{a}$ ) that occurred $35.6 \pm 1.3 \mathrm{~h}$ after the start of GnRH treatment (see Fig. 1). Plasma LH concentrations then returned temporarily to pretreatment levels, but rose again and within $12 \mathrm{~h}$ were significantly $(P<0.01)$ higher than pretreatment concentrations for this group, and significantly $(P<0.01)$ higher than mean values in GnRH-treated control ewes over the same period (see Fig. 1).

The mean LH responses to individual GnRH injections (based on blood samples collected at 15-min intervals) are shown for $0-12 \mathrm{~h}$ and for $24-30 \mathrm{~h}$ of treatment in Fig. 2 . The last $6 \mathrm{~h}$ of the second period of 15 -min sampling was excluded from the analyses, as this coincided with the onset of the preovulatory LH surge in $4 / 5$ of the control ewes. The mean magnitude of the GnRHinduced LH episodes did not differ significantly between treatment groups $(3.00 \pm 0.39 \mathrm{ng} / \mathrm{ml}$ and $3.63 \pm 0.51 \mathrm{ng} / \mathrm{ml}$ for animals treated with GnRH plus bFF and GnRH alone, respectively), but was significantly $(P<0.01)$ greater than that of endogenous $\mathrm{LH}$ episodes $(1.71 \pm 0.22 \mathrm{ng} / \mathrm{ml})$ recorded over the pretreatment period.

Plasma FSH concentrations. Mean FSH profiles are shown in Fig. 1(b). Over the pretreatment period mean plasma FSH concentrations did not differ significantly between treatment groups $(19.0 \pm 4.4$ and $19.8 \pm 3.7 \mathrm{ng} / \mathrm{ml})$. In control ewes given GnRH alone, FSH concentrations did not change significantly until the onset of a preovulatory FSH surge (mean maximum conc. $65 \cdot 0 \pm 14 \cdot 4 \mathrm{ng} / \mathrm{ml}$ ) which occurred coincident with the preovulatory $\mathrm{LH}$ surge. A second elevation in FSH concentrations (mean maximum conc. $46.9 \pm 8.2 \mathrm{ng} / \mathrm{ml}$ ) was recorded in these animals $25.6 \pm 1.8 \mathrm{~h}$ after the preovulatory FSH surge (see Fig. $3 \mathrm{~b}$ ). In contrast, in those ewes treated with bFF, FSH concentrations fell from the start of treatment to reach a mean concentration of $7 \cdot 4 \pm 1.0 \mathrm{ng} / \mathrm{ml}$ by $12 \mathrm{~h}$ after the first bFF injection, and remained low throughout the rest of the treatment period. Plasma FSH concentrations increased abruptly when treatment with bFF ceased, to attain a mean maximum concentration of $57.2 \pm 8.7 \mathrm{ng} / \mathrm{ml}$ by $23.6 \pm 1.2 \mathrm{~h}$ after the last injection (see Fig. 1b).

\section{Experiment 2}

Gonadotrophin concentrations. For the first $24 \mathrm{~h}$ of treatment mean plasma LH concentrations (based on $2 \mathrm{~h}$ samples taken immediately before each $\mathrm{GnRH}$ injection) did not differ significantly between ewes treated with GnRH alone $(0.65 \pm 0 \cdot 15 \mathrm{ng} / \mathrm{ml})$ and those that were also given $\mathrm{bFF}$ 


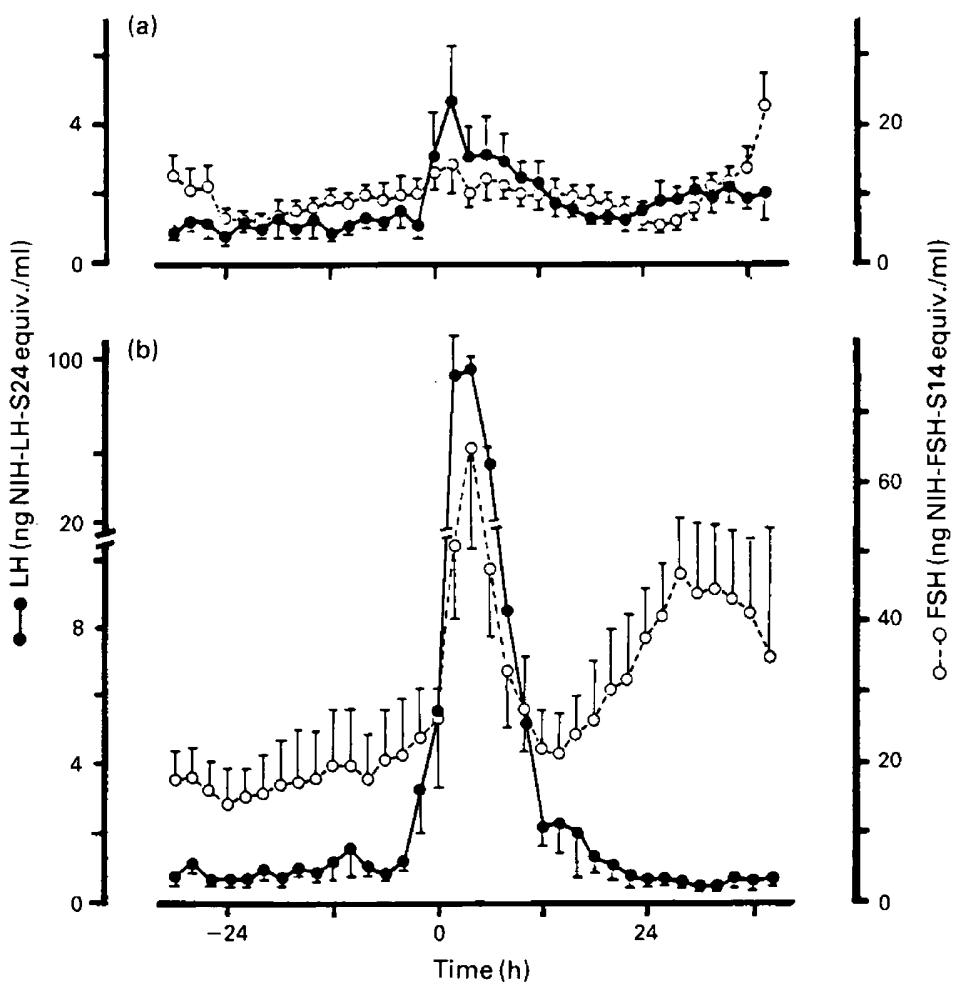

Fig. 3. Mean ( \pm s.e.m.) plasma LH (-O) and FSH $\left(\mathrm{O}_{---} \mathrm{O}\right)$ concentrations in seasonally anoestrous ewes injected with GnRH (250 ng/injection) at 2-h intervals for $72 \mathrm{~h}$ with (a) or without (b) concurrent treatment with bFF $(2 \mathrm{ml})$ given at 8 -h intervals. The data have been normalized about the preovulatory surge in control ewes (b) and about the coincident LH increase in bFF-treated ewes (see text).

$(0.45 \pm 0.13 \mathrm{ng} / \mathrm{ml})$. Over the last $4 \mathrm{~h}$ of treatment, LH concentrations increased dramatically in 3 ewes from each treatment group. However, the mean concentrations attained at this time were significantly $(P<0.05)$ higher in control ewes $(28.63 \pm 4.26 \mathrm{ng} / \mathrm{ml})$ than in bFF-treated animals $(5.65 \pm 1.6 \mathrm{ng} / \mathrm{ml})$. None of the ewes showed oestrus.

Mean plasma FSH concentrations over the last $18 \mathrm{~h}$ of the treatment period were significantly $(P<0.01)$ lower in animals receiving injections of bFF $(11.6 \pm 1.8 \mathrm{ng} / \mathrm{ml})$, than in those treated with $\mathrm{GnRH}$ alone $(21 \cdot 3 \pm 1 \cdot 1 \mathrm{ng} / \mathrm{ml})$.

Antral follicle characteristics. The mean diameter of the 3 largest antral follicles present in each animal at the time of slaughter, and their atretic classifications, are shown in Table 1 . The mean diameter of the largest follicle from each animal was significantly $(P<0.001)$ greater in ewes treated with GnRH alone. In contrast, the mean size of the second and third largest follicles did not differ significantly between treatment groups.

The incidence of an advanced state of atresia (Classes IV and V) was significantly $(P<0.05)$ higher in ewes treated with bFF. In addition, all GnRH-treated control ewes had at least one healthy (Class I or II) follicle present. In contrast, only one bFF-treated ewe had one or more follicles present that were classified as healthy. 
Table 1. The mean diameter and atretic classification (in parentheses) of the three largest follicles present in seasonally anoestrous ewes slaughtered after $32 \mathrm{~h}$ of treatment with GnRH alone (Ewes 16-20) or with GnRH plus bFF (Ewes 11-15)

\begin{tabular}{|c|c|c|c|c|}
\hline \multirow[b]{2}{*}{ Treatment } & \multirow[b]{2}{*}{$\begin{array}{l}\text { Ewe } \\
\text { no. }\end{array}$} & \multicolumn{3}{|c|}{$\begin{array}{l}\text { Follicle size* }(\mathrm{mm}) \\
\text { and atretic classification } \dagger\end{array}$} \\
\hline & & $\begin{array}{l}\text { First } \\
\text { follicle }\end{array}$ & $\begin{array}{l}\text { Second } \\
\text { follicle }\end{array}$ & $\begin{array}{l}\text { Third } \\
\text { follicle }\end{array}$ \\
\hline \multirow[t]{2}{*}{ GnRH alone } & $\begin{array}{l}16 \\
17 \\
18 \\
19 \\
20\end{array}$ & $\begin{array}{l}5.50 \text { (I) } \\
6.10 \text { (I) } \\
5.75 \text { (II) } \\
5.75 \text { (IV) } \\
6.50 \text { (II) }\end{array}$ & $\begin{array}{l}5.40 \text { (I) } \\
2.80 \text { (IV) } \\
5.10 \text { (II) } \\
5.25 \text { (II) } \\
2.60 \text { (V) }\end{array}$ & $\begin{array}{l}3.25 \text { (II) } \\
2.50 \text { (V) } \\
4 \cdot 10 \text { (II) } \\
3.00 \text { (III) } \\
2 \cdot 50 \text { (IV) }\end{array}$ \\
\hline & Mean \pm s.e.m. & $5.92 \pm 0 \cdot 17^{b}$ & $4 \cdot 23 \pm 0.63^{a}$ & $3.07 \pm 0.30^{\mathrm{a}}$ \\
\hline \multirow[t]{2}{*}{$\mathrm{GnRH}+\mathrm{bFF}$} & $\begin{array}{l}11 \\
12 \\
13 \\
14 \\
15\end{array}$ & $\begin{array}{l}4 \cdot 25 \text { (IV) } \\
3 \cdot 50 \text { (III) } \\
4 \cdot 20 \text { (III) } \\
3.75 \text { (IV) } \\
4.00 \text { (II) }\end{array}$ & $\begin{array}{l}3 \cdot 10 \text { (IV) } \\
3 \cdot 00 \text { (IV) } \\
4 \cdot 10 \text { (IV) } \\
3 \cdot 50 \text { (IV) } \\
3 \cdot 60 \text { (IV) }\end{array}$ & $\begin{array}{l}2.90 \text { (IV) } \\
2.75 \text { (IV) } \\
3.90 \text { (III) } \\
3.50 \text { (IV) } \\
3.50 \text { (II) }\end{array}$ \\
\hline & Mean \pm s.e.m. & $3.94 \pm 0 \cdot 14^{\mathrm{a}}$ & $3.46 \pm 0 \cdot 20^{\mathrm{a}}$ & $3.31 \pm 0.21^{\mathrm{a}}$ \\
\hline
\end{tabular}

*Within columns means with different superscripts are significantly different (a v b, $P<0.001)$.

†Follicles were assessed for atresia on the basis of the integrity of the membrana granulosa with Class I being the healthiest and Class $V$ the most atretic (see text).

\section{Discussion}

In earlier studies in which ovulation has been induced in seasonally anoestrous ewes by repeated injections of GnRH, FSH secretion was not stimulated (McLeod \& Haresign, 1987). This suggested that FSH was not directly involved in the final stages of growth and development of preovulatory follicles. In contrast, when FSH secretion was suppressed by administration of bFF in this study, GnRH-induced follicle development was impaired and ovulation did not occur. This may be indicative of the requirement for a critical level of plasma FSH concentrations over the period of GnRH-stimulated follicle growth, or alternatively, may be the result of inhibitory effects of bFF acting directly on the ovary or at the hypothalamo-pituitary axis.

Treatment with bFF did not abolish FSH secretion in the seasonally anoestrous ewe, but reduced plasma concentrations to about $50 \%$ of pretreatment levels. This suppression was maintained until the onset of the 'rebound' in FSH concentrations that occurred about $24 \mathrm{~h}$ after the last bFF injection (see Fig. 1). These responses are similar, in both timing and magnitude, to those associated with i.v. administration of bFF during the breeding season (McNeilly, 1984, 1985; Wallace \& McNeilly, 1985). In addition, when the hormone profiles were standardized about the preovulatory surge, the pattern of FSH secretion monitored in the control ewes (see Fig. 3b) was comparable to that previously reported for GnRH-treated anoestrous ewes (McLeod \& Haresign, 1987), and indeed, to that observed for naturally-cycling ewes during the breeding season (Salamonsen et al., 1973; Pant et al., 1977). For the first $30 \mathrm{~h}$ of treatment mean plasma LH concentrations, and the $\mathrm{LH}$ response to $\mathrm{GnRH}$ injections, did not differ between treatment groups. This indicates that the level of output of those ovarian steroids that are involved in negative feedback 
was similar in both groups of animals, at least over this early period of GnRH treatment. This is surprising, as it is widely accepted that FSH plays a major role in the conversion of androgens to oestradiol-17ß (Baird, 1977; Dorrington \& Armstrong, 1979), and that oestradiol-17 $\beta$ is the principal ovarian steroid contributing to negative feedback in the sheep (Baird \& McNeilly, 1981). In animals treated with bFF in this study, maximum suppression of FSH was attained within $12 \mathrm{~h}$ of the start of treatment. In ewes treated with bFF during the breeding season, characteristics of $\mathrm{LH}$ secretion do not change in the short term (McNeilly, 1984, 1985). However, after an extended period ( $>3$ days) of bFF treatment, there is a significant increase in both the frequency and the amplitude of LH episodes (Wallace \& McNeilly, 1986).

The precise characteristics of the short-lived elevation in plasma LH concentrations that occurred in bFF-treated ewes in this study, and that was coincident with the preovulatory surge in control animals, remain to be determined. Blood samples were taken at 2 -h intervals immediately before each GnRH injection and therefore would have monitored baseline LH concentrations. The elevation in LH concentrations may have been due to a sudden increase in the magnitude of the GnRH-induced LH episodes, such that plasma concentrations did not return to baseline values between successive GnRH injections. This would suggest that there was an abrupt, but transient, removal of negative feedback influences from the ovary. An alternative explanation is that there was an increase in the magnitude of GnRH-induced LH episodes due to GnRH priming of the pituitary, independent of oestradiol. A third possibility is that this increase in LH levels represents an 'inadequate' preovulatory LH surge. This would suggest that the GnRH treatment stimulated follicle growth and thus promoted oestradiol production, to the point where the positive feedback response was initiated but, perhaps due to an insufficiency of ovarian steroids or to inhibitory actions of $\mathrm{bFF}$ at the hypothalamo-pituitary axis, the preovulatory surge failed. When this elevation in plasma LH concentrations is synchronized for all bFF-treated ewes (see Fig. 3a), the abrupt nature of its increase and its duration become apparent. These are not dissimilar to the characteristics of preovulatory surge release. It is unlikely that this transient increase in LH concentrations was ram-induced, for although an increase in pulsatile $\mathbf{L H}$ secretion is associated with the ram effect, this occurs within 10-20 min of ram introduction (Martin, 1984). In the present experiment, the rams had been introduced more than 14 days earlier.

After the preovulatory (or inadequate) surge, LH concentrations returned to pretreatment values in all ewes. However, in the animals receiving bFF, LH concentrations soon rose again (Fig. 1a). It is possible that this second increase in $\mathrm{LH}$ concentrations was due to a reduction in the level of ovarian steroids, following the eventual demise of the dominant follicle(s) in each of the bFFtreated ewes. Alternatively, the GnRH-primed pituitary may have been responding more fully to each GnRH injection. However, it is yet to be determined whether the LH response to GnRH injections did increase over this period, although plasma LH concentrations remained elevated even after administration of $\mathrm{GnH}$ had ceased.

None of the bFF-treated ewes ovulated. This may be indicative of inadequate follicular growth in these animals. For example, the mean diameter of the largest follicle present after $32 \mathrm{~h}$ of treatment (and therefore just before the preovulatory surge), was significantly $(P<0.001)$ greater in control ewes than in bFF-treated ewes. In addition, the number of healthy follicles (atretic classification I or II) was significantly $(P<0.05)$ higher in animals given GnRH alone. The mean number of large ( $>5.0 \mathrm{~mm}$ in diameter) healthy follicles present in the control group in Exp. $2(1.4 \pm 0 \cdot 2 /$ ewe) was the same as the mean ovulation rate in the control group in Exp. 1 (1.4 $\pm 0 \cdot 2)$. Nevertheless, it remains to be determined whether the follicles present in bFF-treated ewes after $32 \mathrm{~h}$ of treatment would be capable of ovulating. Further study is required to assess, in detail, steroid production by these follicles, and to determine their ability to ovulate if exposed to a normal preovulatory surge.

Finally, it must be emphasized that the current experiments used a relatively crude bFF preparation to suppress FSH secretion. It has been demonstrated that, as well as inhibin, follicular fluid preparations contain numerous biologically active moieties (see Tsonis \& Sharpe, 1986). Therefore, the responses recorded may not be due specifically to FSH suppression. 
We thank the A.F.R.C. for financial support, Hoechst Pharmaceuticals for supplies of GnRH and the National Institutes of Health for standard LH and FSH.

\section{References}

Baird, D.T. (1977) Evidence in vivo for the two-cell hypothesis of oestrogen synthesis by the sheep Graafian follicle. J. Reprod. Fert. 50, 183-185.

Baird, D.T. \& McNeilly, A.S. (1981) Gonadotrophic control of follicular development and function during the oestrous cycle of the ewe. J. Reprod. Fert., Suppl. 30, 119-133.

Carson, R.S., Findlay, J.K. Burger, H.G. \& Trounson, A.D. (1979) Gonadotropin receptors of the ovine ovarian follicle during follicular growth and atresia. Biol. Reprod. 21, 75-87.

Dorrington, J.H. \& Armstrong, D.T. (1979) Effects of FSH on gonadal function. Recent Prog. Horm. Res. 35, 301-333.

Foster, J.P. \& Crighton, D.B. (1974) Luteinizing hormone $(\mathrm{LH})$ release after single injections of synthetic LH-releasing hormone (LH-RH) in the ewe at three different reproductive stages and comparison with natural LH release at oestrus. Theriogenology 2, 87-100.

Hunter, M.G., Southee, J.A., McLeod, B.J. \& Haresign, W. (1986) Progesterone pretreatment has a direct effect on GnRH-induced preovulatory follicles to determine their ability to develop into normal corpora lutea in anoestrous ewes. J. Reprod. Fert. 76, 349-363.

Martin, G.B. (1984) Factors affecting the secretion of LH in the ewe. Biol. Rev. 59, 1-87.

McLeod, B.J. \& Haresign, W. (1987) Plasma FSH concentrations in seasonally anoestrous ewes induced to ovulate with repeated injections or continuous infusion of GnRH. Anim. Reprod. Sci. 14 (in press).

McLeod, B.J., Haresign, W. \& Lamming, G.E. (1982) Response of seasonally anoestrous ewes to smalldose multiple injections of GnRH with and without progesterone pretreatment. J. Reprod. Fert. 65, 223-230.

McLeod, B.J., Haresign, W. \& Lamming, G.E. (1983) Induction of ovulation in seasonally anoestrous ewes by continuous infusion of low doses of GnRH. $J$. Reprod. Fert. 68, 489-495.

McNeilly, A.S. (1984) Changes in FSH and the pulsatile secretion of $\mathrm{LH}$ during the delay in oestrus induced by treatment of ewes with bovine follicular fluid. $J$. Reprod. Fert. 72, 165-172.

McNeilly, A.S. (1985) Effect of changes in FSH induced by bovine follicular fluid and FSH infusion in the preovulatory phase on subsequent ovulation rate and corpus luteum function in the ewe. J. Reprod. Fert. $74,661-668$.
McNeilly, A.S., O'Connell, M. \& Baird, D.T. (1982) Induction of ovulation and normal luteal function by pulsed injections of luteinizing hormone in anestrous ewes. Endocrinology 110, 1292-1299.

McNeilly, A.S., Wallace, J.M. \& Baird, D.T. (1985) Induction of ovulation in anoestrous ewes using gonadotrophins. In Endocrine Causes of Seasonal and Lactational Anoestrus in Farm Animals, pp. 66-75. Eds F. Ellendorf \& F. Elsaesser. Martinus Nijhoff, Dordrecht.

McNeilly, A.S., Jonassen, J.A. \& Fraser, H.M. (1986) Suppression of follicular development after chronic LHRH immunoneutralization in the ewe. J. Reprod. Fert. 76, 48 I -490.

McNeilly, J.R., McNeilly, A.S., Walton, J.S. \& Cunningham, F.J. (1976) Development and application of a heterologous radioimmunoassay for ovine follicle-stimulating hormone. J. Endocr. 70, 69-79.

Miller, K.F., Critser, J.K., Rowe, R.F. \& Ginther, D.J. (1979) Ovarian effects of bovine follicular fluid treatment in sheep and cattle. Biol. Reprod. 21, 537-544.

Pant, H.C., Hopkinson, C.R.N. \& Fitzpatrick, R.J. (1977) Concentration of oestradiol, progesterone, luteinizing hormone and follicle-stimulating hormone in the jugular venous plasma of ewes during the oestrous cycle. J. Endocr. 73, 247-255.

Salamonsen, L., Jonas, H.H., Burger, H.C., Buckmaster, J.M., Chamley, W.A., Cumming, I.A., Findlay, J.K. \& Goding, J.R. ( I973) A heterologous radioimmunoassay for follicle-stimulating hormone; application to measurements of FSH in the ovine estrous cycle and in several other species including man. Endocrinology 93, 610-618.

Tsonis, C.G. \& Sharpe, R.M. (1986) Dual gonadal control of follicle-stimulating hormone. Nature, Lond. 321, $724-725$.

Tsonis, C.G., McNeilly, A.S. \& Baird, D.T. (1986) Measurement of exogenous and endogenous inhibin in sheep serum using a new and extremely sensitive bioassay for inhibin based on inhibition of ovine pituitary FSH secretion in vitro. $J$. Endocr. 110, 341-353.

Wallace, J.M. \& McNeilly, A.S. (1985) Increase in ovulation rate after treatment of ewes with bovine follicular fluid in the luteal phase of the oestrous cycle. $J$. Reprod. Fert. 73, 505-515.

Wallace, J.M. \& McNeilly, A.S. (1986) Changes in FSH and the pulsatile secretion of LH during treatment of ewes with bovine follicular fluid throughout the luteal phase of the oestrous cycle. J. Endocr. 111, 317-327. 